\title{
Power of a multidisciplinary approach: use of morphological, molecular and digital methods in the study of harpacticoid cryptic species
}

\author{
Ernestina Castro-Longoria ${ }^{1, *}$, Josué Alvarez-Borrego ${ }^{1}$, Axayácatl Rocha-Olivares ${ }^{2}$, \\ Samuel Gomez ${ }^{3}$, Vitaly Kober ${ }^{4}$ \\ ${ }^{1}$ Departamento de Óptica, Centro de Investigación Científica y de Educación Superior de Ensenada, ${ }^{2}$ Departamento de Ecología, \\ and ${ }^{4}$ Departamento de Ciencias de la Computación, AP 2732, Ensenada Baja California 22860, Mexico \\ ${ }^{3}$ Universidad Nacional Autónoma de México, Instituto de Ciencias del Mar y Limnología, AP 811, Mazatlán, Sinaloa 82040, Mexico
}

\begin{abstract}
A multidisciplinary approach amenable to automation and involving digital techniques in conjunction with detailed taxonomical observations and molecular genetic analyses was used to assess the phenotypic and genetic variability of 3 harpacticoid copepods previously identified as Cletocamptus deitersi. C. deitersi may be the most problematic species among congeners due to its intraspecific morphological variability. Specimens of $C$. deitersi collected from inland and coastal habitats in Alabama, California and Louisiana were analyzed to determine the degree of separation between specimens. Levels of extreme genetic differentiation at both mitochondrial and nuclear loci and incipient but congruent morphological differences among specimens of the 3 populations strongly suggest that each genetic lineage belongs to a different species. Discrimination among species was also detected using a digital correlation method invariant to position and rotation. This analysis involved an algorithm using the square module of the fast Fourier transform. Digital images of specimens from the 3 populations were processed to obtain their diffraction patterns. To discriminate among species, all diffraction patterns were correlated with a special filter containing different random fixed views of each species. Results indicate that new identification methods of microscopic organisms could be developed to reduce the amount of time of direct observation. In order to build these methods on a solid taxonomic validation, it is necessary to implement a multidisciplinary approach in which expertise in taxonomy, molecular biology and digital processing work in conjunction to maximize their reliability and precision.
\end{abstract}

KEY WORDS: Cletocamptus deitersi - Cryptic species · Digital correlation $\cdot \mathrm{mtDNA} \cdot \mathrm{ITS} \cdot \mathrm{Morphological}$ variation

Resale or republication not permitted without written consent of the publisher

The problem. One of the most challenging questions in contemporary biology is the assessment and conservation of biodiversity at a rate faster than its loss (e.g. Bininda-Emonds et al. 2000). Empirical evidence points to the tight coupling between regional marine

*Email: ecastro@cicese.mx biodiversity and environmental parameters (e.g. Zacharias \& Roff 2001). In the face of inexorable climate change, there is an increasing need to establish baselines of species diversity and of their ecological interactions to understand the consequences of global warming (Harrington et al. 1999). An obstacle that has hindered our understanding of ecological and evolutionary processes has been our inability to recognize morphologically very similar cryptic or pseudo-cryptic species (e.g. Knowlton 1993). Failure to identify the existence of cryptic biodiversity has potential negative consequences in the study of evolutionary and ecological processes. Among others, some of these problems are that true levels of species richness can be grossly underestimated, taxonomic and systematic uncertainty may prevail, the potential for long-distance dispersal in putatively cosmopolitan species can be overestimated, cryptic biological invasions can go unnoticed, and ecological and paleoecological data can be misinterpreted (Knowlton et al. 1992, Geller et al. 1997, de Vargas et al. 1999, Klautau et al. 1999). Cryptic species appear to occur particularly among small metazoans, as a consequence of a simple and conservative morphology (e.g. Todaro et al. 1996); this is true of harpacticoid copepods (e.g. Ganz \& Burton 1995). The fact that individuals of some small species $(<0.5 \mathrm{~mm})$ are difficult to tell apart even in the presence of detailed morphological observations begs the question whether new techniques can be developed for species identification that could reduce the time of direct observation and would be amenable to automation. This is particularly important for ecological studies, in which the time required for dissection and detailed examination of a large number of individuals is generally prohibitive. 
The 'species'. In 1897, Richard described a new species of Mesochra, Mesochra (= Cletocamptus) deitersi from Naposta Grande River, presumably close to the city of Naposta, Argentina. No accurate indication of the type-locality or geographic position was provided and, more unfortunately, no reference material of the new species was preserved. Subsequently, C. deitersi has been reported from inland brines as well as coastal estuaries and mangroves from North, Central and South America, India, China, Ethiopia and Malaysia. This species is well known for its high degree of polymorphism within and between populations (Fleeger 1980). Its naupliar stages develop in the benthic realm, and only the copepodids and adults are capable of some limited dispersal through the water column (Sun \& Fleeger 1994). This limits long-distance migration, making colonization events rare and gene flow limited among populations (Rocha-Olivares et al. 2001). C. deitersi seems to be the most problematic species in the genus due to its intraspecific variability, mainly of the swimming-leg armature formulae (e.g. Löffler 1963, Fleeger 1980). New specimens of Cletocamptus from remote localities throughout North, Central and South America, India, China, Ethiopia and Malaysia may have been erroneously identified as $C$. deitersi due to the absence of subtle structural details in the original description. Several authors (e.g. SuárezMorales et al. 1996, Gee 1999, Mielke 2000) have suggested that $C$. deitersi consists of a number of morphologically indistinguishable sibling species. Recent genetic evidence indicates that some North American populations of $C$. deitersi represent cohesive evolutionary units deserving a species status. RochaOlivares et al. (2001) found 4 extremely divergent molecular lineages in specimens of $C$. deitersi collected from inland and coastal habitats in Alabama, California, Louisiana (USA) and Sinaloa (Mexico), finding that subtle differences in morphology were congruent with the patterns of genetic differentiation. Comparative analyses suggest that these major lineages belong to different species.

The approach. Given the challenging nature of the problem, we propose the use of a synergistic, interdisciplinary approach that combines genetic, morphological, and digital methods to identify, describe, and automate species determination of closely related and poorly differentiated organisms for which diagnostic molecular and digital properties can be characterized. In earlier attempts to identify zooplankton species using silhouette photography (Ortner et al. 1979) or video-camera imaging (e.g. Latrous 1984, Rolke \& Lenz 1984), organisms' spatial orientation and image resolution were limiting factors for correct taxonomic determination. Digital diffraction-pattern analyses (DDPA) have provided an improvement for plank- ton identification (Zavala-Hamz et al. 1996, ZavalaHamz \& Alvarez-Borrego 1997, Pech-Pacheco et al. 1999). For instance, Castro-Longoria et al. (2001) used this method to discriminate 5 non-congeneric copepod species. Here, we adopt a multidisciplinary approach using DDPA in conjunction with detailed morphological observations and molecular genetic analyses to assess the phenotypic and genetic variability of 3 populations of Cletocamptus, previously identified as $C$. deitersi. We assess the utility of the DDPA to discriminate among these very similar harpacticoid copepods.

Materials and methods. Sampling and analyses were as follows.

Sampling: Sediment samples were collected from an inland brine seep (Alabama, 31 $23^{\prime} \mathrm{N}, 87^{\circ} 53^{\prime} \mathrm{W}$ ) and at 2 locations on the Gulf of Mexico coast (Louisiana: Port Fourchon, $29^{\circ} 05.4^{\prime} \mathrm{N}, 90^{\circ} 05.8^{\prime} \mathrm{W}$ and Cocodrie, $\left.29^{\circ} 15.2^{\prime} \mathrm{N}, 90^{\circ} 39.8^{\prime} \mathrm{W}\right)$. Specimens of Cletocamptus were also obtained from collections made in the Salton Sea (California, 33 $13^{\prime} \mathrm{N}, 115^{\circ} 52^{\prime} \mathrm{W}$ ). These habitats differ considerably in environmental parameters (RochaOlivares et al. 2001). Field-collected copepods were removed from sieved sediment and fixed in 95\% ethanol. Two more harpacticoids, a congener species C. helobius and Coullana sp., were collected from Alabama sediment and used for genetic comparisons.

Morphological analyses: Material for morphological descriptions was preserved in $70 \%$ ethanol. Observations were made from whole and dissected glycerinemounted specimens using a phase-contrast compound microscope $(1000 \times)$. We adopted the terminology proposed by Huys \& Boxshall (1991) for anatomical descriptions. Abbreviations used henceforth are: P1-P6, first to sixth swimming leg; EXP, exopod; ENP, endopod; ENP2 and ENP3, second and third endopodal segment, respectively. Detailed taxonomical descriptions and the names of several new species of Cletocamptus from the material of this study will be published elsewhere (Gomez et al. unpubl.). Here, we refer to the 3 new species of copepods as Cletocamptus by the locality of collection: Alabama, California and Louisiana.

Molecular analyses: The molecular analyses have been published elsewhere (Rocha-Olivares et al. 2001). Briefly, 2 mitochondrial regions (COX-I and 16S rDNA) and 1 nuclear (ITS1-5.8S-ITS2) gene region were PCR-amplified and sequenced in copepods from each sampling locality. DNA sequence data were used to reconstruct molecular phylogenies using distance and character-based methods (see Rocha-Olivares et al. 2001 for details).

Digital image analyses: Adult male and female Cletocamptus from the 3 localities (see above) were used for the digital study. Specimens were observed under a light microscope and their images digitally captured using a Charge Coupled Device (CCD) camera con- 
nected to a computer. For each species, 30 images $(256 \times 256$ pixels $), f(x, y)$ were captured from each of 15 specimens, where $f$ is the variable defining the image. The first step in the analysis involves choosing different random fixed views (RFV) of each species, denoted $f_{1}(x, y), f_{2}(x, y), \ldots, f_{\mathrm{n}}(x, y)$ (Fig. 1a). For each image, the square modulus of the fast Fourier transform is computed to assess position invariance, $\left|F_{1}\left(w_{\mathrm{x}}, w_{\mathrm{y}}\right)\right|^{2},\left|F_{2}\left(w_{\mathrm{x}}, w_{\mathrm{y}}\right)\right|^{2}, \ldots,\left|F_{\mathrm{n}}\left(w_{\mathrm{x}}, w_{\mathrm{y}}\right)\right|^{2}$ (Fig. 1b), where $f$ is the variable defining the Fourier transform of the image and $w$ defines the coordinates in $x$ and $y$ directions. Then, all diffraction patterns (DP) are added to get a single DP containing all the information of the different RFVs, $\left|F\left(w_{\mathrm{x}}, w_{\mathrm{y}}\right)\right|^{2}$ (Fig. 1c). High frequencies are then enhanced using a high-pass filter (Pech-Pacheco et al. 2003) so that diffraction patterns are observed in more detail (Fig. 1d). This step is very important because, with the high-frequency enhancement, fine details of the organism image are also enhanced. Next, to have rotation invariance, the Cartesian coordinates $\left(w_{\mathrm{x}}, W_{\mathrm{y}}\right)$ are mapped to polar coordinates, $F(\mathrm{r}, \theta)$ (Fig. 1e). The fast Fourier transform is then applied to the polar-mapped data to obtain the composite phase filter, $S_{\mathrm{cpf}}\left(u_{\rho}, v_{\theta}\right)$ (where $S_{\mathrm{cpf}}$ defines the composite phase filter, $u_{\rho}$ and $v_{\theta}$ are the coordinates of the filter), which summarizes the digital properties of the species to be recognized. This filter (Fig. 1f) will be used in the position, rotation invariant correlation. To discriminate among the species, all images were transformed as in Fig. 1, except that in Step 1a there was only 1 image in the input. The result of this process was correlated with the composite phase filter obtained for each species (see Fig. 1f).

Results and discussion. The morphological, molecular and digital image analyses revealed the following.

Morphological analyses: When Cletocamptus deitersi was described, only 3 other congeneric species were known (C. retrogressus Schmankewitsch, 1875; C. albuquerquensis Herrick, 1894; and C. confluens Schmeil, 1894). Richard's (1897) brief description of $C$. deitersi appears to be distinct enough to separate it from the other species of Cletocamptus. Subsequently, C. deitersi has been reported from distant localities. Analyses of $C$. deitersi material deposited at the US National Museum (Washington) and the Natural History Museum (London) from North, Central and South America support the creation of several new congeneric species (S. Gomez pers. obs.). Misidentification of Cletocamptus from North, Central and South America with the Argentinean C. deitersi is probably the result of insufficient descriptive detail in both the identification and description of new records. Morphological differences observed among specimens of Cletocamptus from Alabama, California and Louisiana are sometimes subtle but congruent with the mol- ecular lineages first reported by Rocha-Olivares et al. (2001). The most striking differences among specimens from Alabama, California and Louisiana are the surface ornamentation of body somites, anal operculum and armature formula of mandibular palp, shape of the lateral spine of the maxillule, and armature formula of female P3, male and female P4, and male P3 ENP2 and ENP3. In Fig. 2 some of the taxonomic differences mentioned above are presented; the full taxonomic illustration will be published elsewhere (Gomez et al. unpubl.).

Molecular analyses: mtDNA gene-trees featured long branches (i.e. major lineages), in excess of $30 \%$ corrected sequence divergence separating Cletocamptus haplotypes from each geographic locality and the other congeneric and non-congeneric species. mtDNA gene trees were well resolved and completely congruent. Nucleotide variation in the 5.8S rDNA gene was insufficient to resolve phylogenetic relationships within Cletocamptus (see Figs. 3 \& 4 in Rocha-Olivares et al. 2001). On the other hand, sequence variation in both ITS regions was extreme among the 3 major lineages, making the nucleotide alignment highly unreliable (see Fig. 2 in Rocha-Olivares et al. 2001). All copepods from California were monophyletic in a major lineage. Copepods from the other 2 lineages were found in sympatry in Alabama and Louisiana. Levels of genetic differentiation among the $3 C$. deitersi lineages were very similar to those between $C$. deitersi and the congener C. helobius (see Fig. 3 in Rocha-Olivares et al. 2001). The extreme genetic differentiation at mitochondrial and nuclear loci, the molecular phylogenies of the genes analyzed, the reproductive isolation suggested by the sympatry of at least 2 of the 3 lineages, and the incipient but congruent level of morphological differentiation strongly suggest that each of the 3 molecular lineages represents a different species.

Digital imaging analyses: The 3 filters containing the information of each lineage were correlated against the diffraction patterns of all individual organisms (correlation values are in relative units). Fig. 3 shows box plots of the means $( \pm \mathrm{SE}$ ) of the 3 filters applied to each group of organisms. When applied to copepods from Alabama, the filter constructed with Cletocamptus from this population was highly auto-correlated (mean $0.24 \pm 0.02$ ). This value was significantly different from those obtained with the specimens from the other 2 localities (Fig. 3a). The same was true for the filter of Cletocamptus from California (mean $0.22 \pm 0.02$ ); this filter was also able to discriminate between Cletocamptus from California and the organisms from Alabama and Louisiana (Fig. 3b). The autocorrelation of the filter for Louisiana was smaller (mean $0.19 \pm$ $0.02)$ and values slightly overlapped $( \pm 2 \mathrm{SE})$ those of California. However, at $\pm 1 \mathrm{SE}$ it was still possible to 


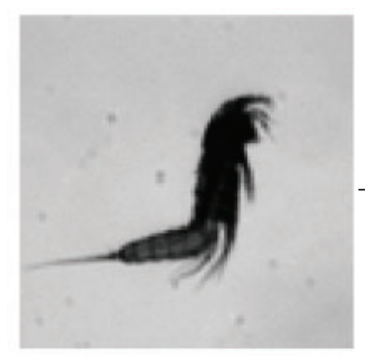

$f_{1}(x, y)$

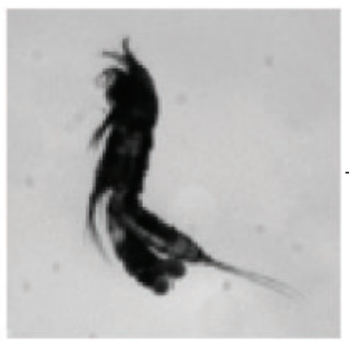

$f_{2}(x, y)$

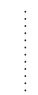

$\nabla$

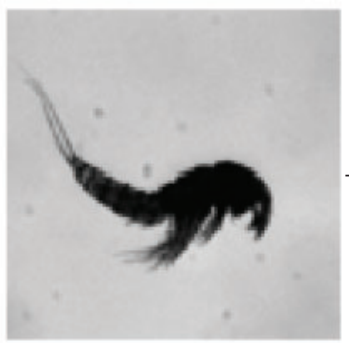

$f_{\mathrm{n}}(x, y)$

a

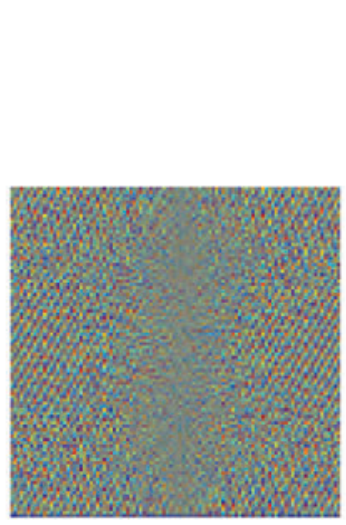

$\mathrm{S}_{\mathrm{cpf}}\left(u_{\rho}, v_{\theta}\right)$

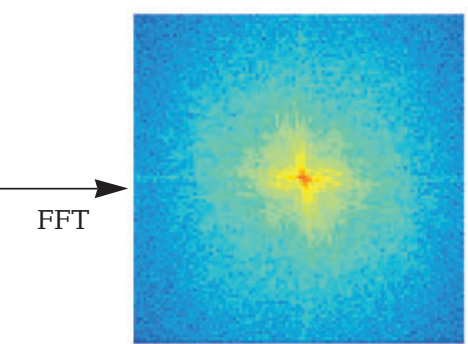

$\left|\mathrm{F}_{1}\left(w_{\mathrm{x}}, w_{\mathrm{y}}\right)\right|^{2}$

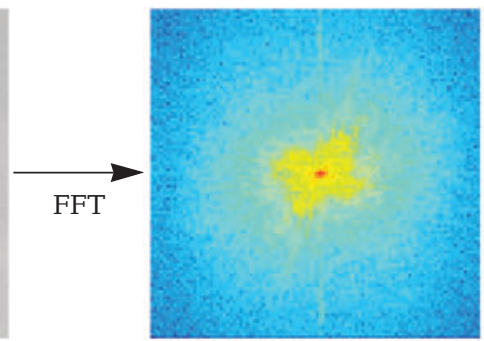

$\left|\mathrm{F}_{2}\left(w_{\mathrm{x}}, w_{\mathrm{y}}\right)\right|^{2}$

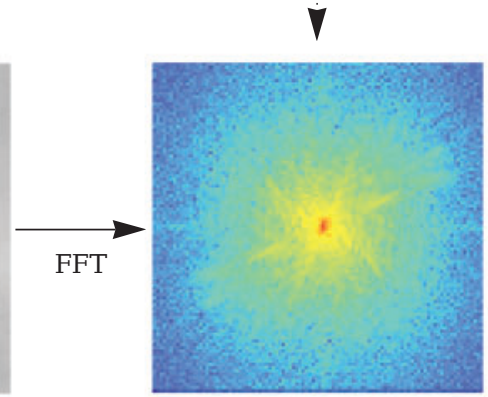

$\left|\mathrm{F}_{\mathrm{n}}\left(w_{\mathrm{x}}, w_{\mathrm{y}}\right)\right|^{2}$

b

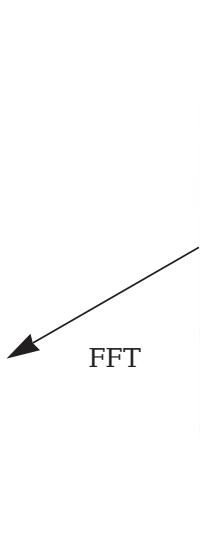

FFT

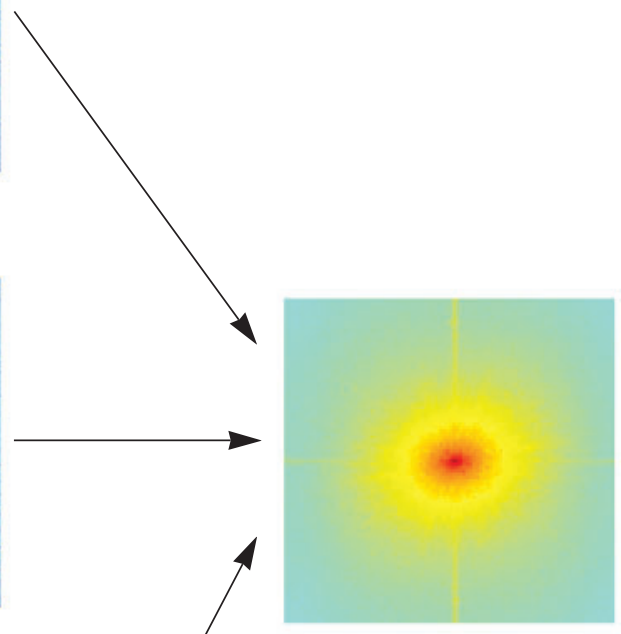

$\left|\mathrm{F}\left(w_{\mathrm{x}}, w_{\mathrm{y}}\right)\right|^{2}$

C
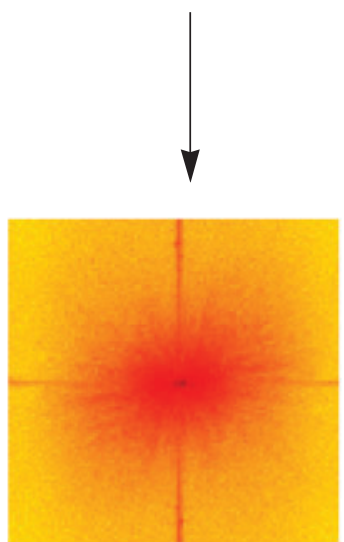

d

\section{f}

Fig. 1. Flow diagram representing the steps followed to obtain the composite filters. (a) Representative digital images of Cletocamptus deitersi, (b) square modulus of the fast Fourier transform (FFT) of each image, (c) sum of all-square modulus, (d) high frequencies enhanced, (e) scale factor applied, (f) composite filter obtained. (See last paragraph of 'Materials and methods' for details) 


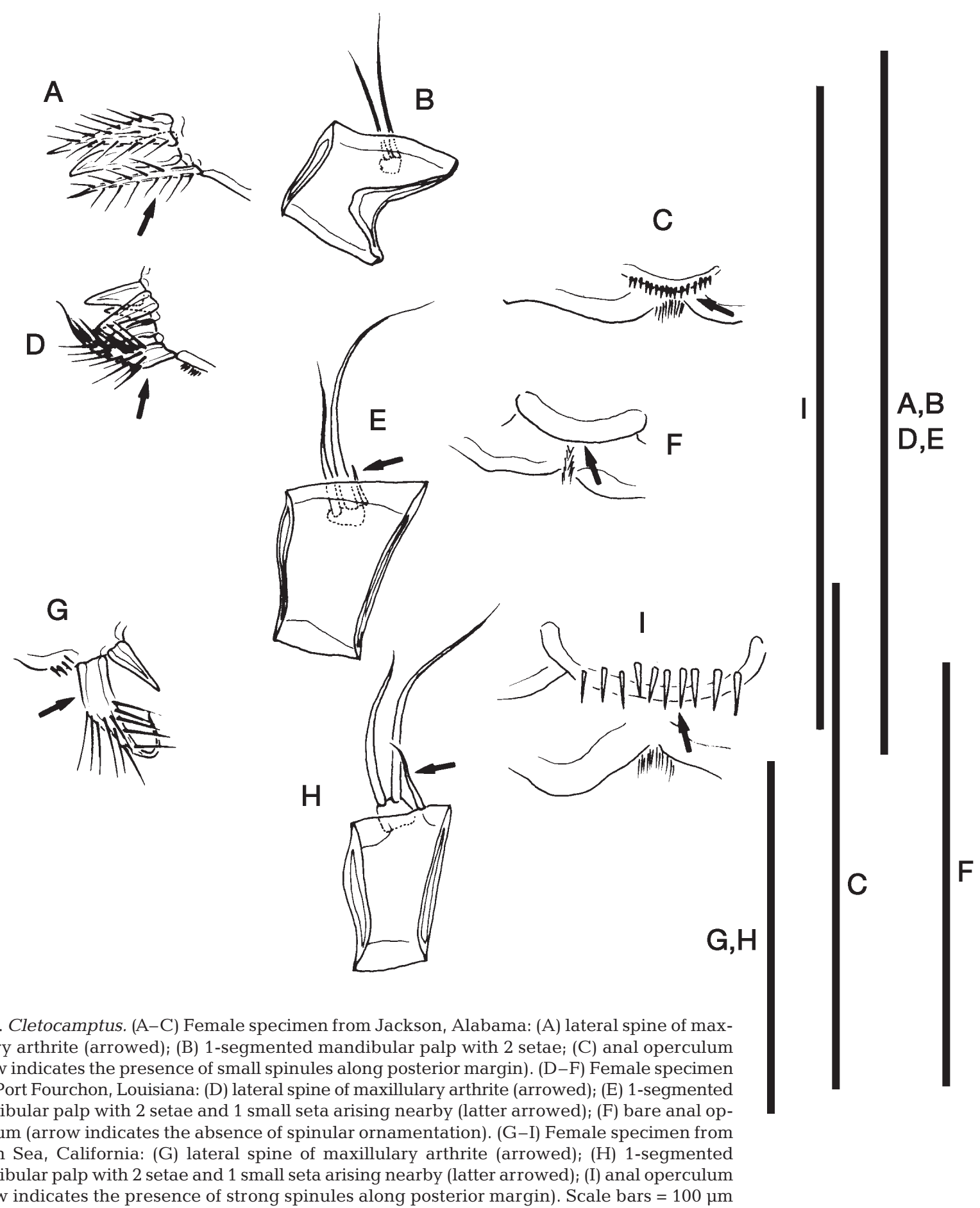

Fig. 2. Cletocamptus. (A-C) Female specimen from Jackson, Alabama: (A) lateral spine of maxillulary arthrite (arrowed); (B) 1-segmented mandibular palp with 2 setae; (C) anal operculum (arrow indicates the presence of small spinules along posterior margin). (D-F) Female specimen from Port Fourchon, Louisiana: (D) lateral spine of maxillulary arthrite (arrowed); (E) 1-segmented mandibular palp with 2 setae and 1 small seta arising nearby (latter arrowed); (F) bare anal operculum (arrow indicates the absence of spinular ornamentation). (G-I) Female specimen from Salton Sea, California: (G) lateral spine of maxillulary arthrite (arrowed); (H) 1-segmented mandibular palp with 2 setae and 1 small seta arising nearby (latter arrowed); (I) anal operculum (arrow indicates the presence of strong spinules along posterior margin). Scale bars $=100 \mu \mathrm{m}$

separate them from the other 2 groups (Fig. 3c). Considering the autocorrelation values obtained by this method, $93.3 \%$ of the values obtained for Cletocamptus from Alabama are in the interval of 2 SE. In the case of Cletocamptus from California, the percentage obtained was $86.6 \%$ and for Cletocamptus from Louisiana it was $76.6 \%$. Despite the similarity in body shape and considering that the differences between species are subtle, it can be observed that the digital correlation technique has the sensitivity and effectiveness to discriminate among them. The discrimination of the digital correlation method invariant to position and rotation is unlikely to focus on the specific differences of systematic and taxonomic relevance. The fact that it can still statistically differentiate among whole-body digitized morphologies is a promising finding. The 

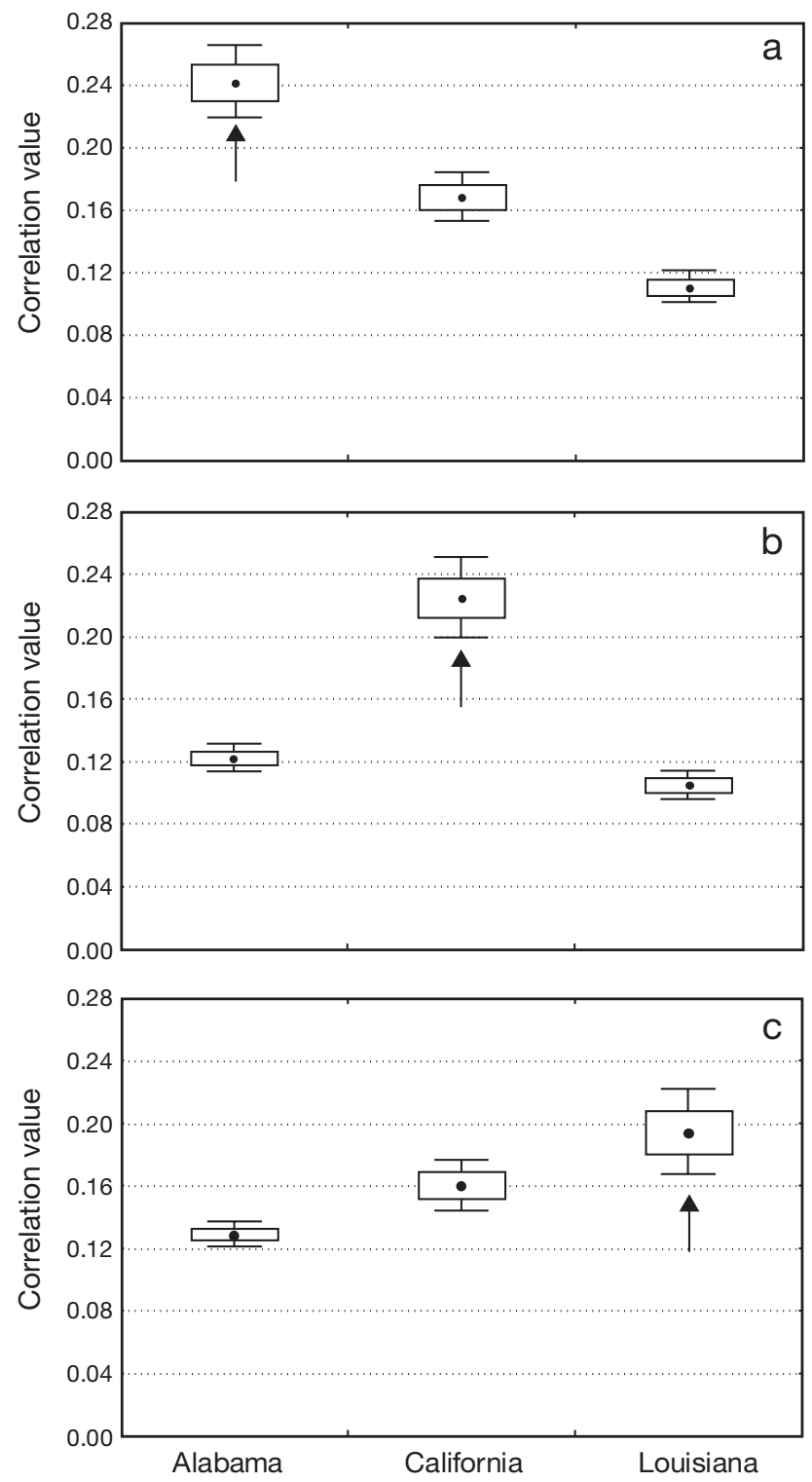

Fig. 3. Cletocamptus. Mean $(\bullet)$ correlation values of diffraction patterns using the following composite filters: (a) Cletocamptus from Alabama; (b) Cletocamptus from California; (c) Cletocamptus from Louisiana. Boxes represent $\pm 1 \mathrm{SE}$, whiskers $\pm 2 \mathrm{SE}$

digital correlation technique could be improved with an increased image resolution and with the implementation of a new technique for local contrast enhancement, which uses rank-order filters based on spatially adaptive neighborhoods (Kober et al. 2001).

Implications and conclusions: Correct species identification of microscopic organisms is of prime importance in the study of evolutionary and ecological processes. The digital method used in this study is an excellent option for the implementation of an automated system and will optimize the time required for this task. As shown here, the resolution power is suitable for even those species considered cryptic or pseudo-cryptic. An automated system would be of great help for non-taxonomists or when taxonomic expertise is unavailable. However it must be stressed that the taxonomic validation and the value of the species-specific filters relies on the generation of an image catalogue in which taxonomic, molecular and digital processing expertise must be put together in order to obtain a reliable and precise system.

Acknowledgements. Part of this work was supported by the Mexican National Council of Science and Technology (CONACYT, project 36075-B) and a postdoctoral research fellowship to E.C.-L. (CICESE, Optics Department).

\section{LITERATURE CITED}

Bininda-Emonds ORP, Vazquez DP, Manne LL (2000) The calculus of biodiversity: integrating phylogeny and conservation. Trends Ecol Evol 15:92-94

Castro-Longoria E, Alvarez-Borrego J, Pech-Pacheco JL (2001) Identification of species of calanoid copepods using a new invariant correlation algorithm. Crustaceana 74:1029-1039

de Vargas CR, Norris L, Zaninetti S, Gibb W, Pawlowski J (1999) Molecular evidence of cryptic speciation in planktonic foraminifers and their relation to oceanic provinces. Proc Natl Acad Sci USA 96:2864-2868

Fleeger JW (1980) Morphological variation in Cletocamptus (Copepoda: Harpacticoida), with description of a new species from Louisiana salt marshes. Trans Am Microsc Soc 99:25-31

Ganz HH, Burton RS (1995) Genetic differentiation and reproductive incompatibility among Baja California populations of the copepod Tigriopus californicus. Mar Biol 123: 821-827

Gee JM (1999) A new species of Cletocamptus Schmankewitsch 1875 (Copepoda; Harpacticoida) from mangrove forest in Malaysia. Hydrobiologia 412:143-153

Geller JB, Walton ED, Grosholz ED, Ruiz GM (1997) Cryptic invasions of the crab Carcinus detected by molecular phylogeography. Mol Ecol 6:901-906

Harrington R, Woiwod I, Sparks T (1999) Climate change and trophic interactions. Trends Ecol Evol 14:146-150

Huys R, Boxshall GA (1991) Copepod evolution. The Ray Society, London

Klautau M, Russo CAM, Lazoski C, Boury-Esnault N, Thorpe JP, Sole-Cava AM (1999) Does cosmopolitanism result from overconservative systematics? A case study using the marine sponge Chondrilla nucula. Evolution 53:1414-1422

Knowlton N (1993) Sibling species in the sea. Annu Rev Ecol Syst 24:189-216

Knowlton N, Weil E, Weigt LA, Guzman HM (1992) Sibling species in Montastraea annularis, coral bleaching, and the coral climate record. Science 255:330-333

Kober VI, Mozerov MI, Alvarez-Borrego J, Ovseyevich IA (2001) Nonlinear filters with spatially connected neighborhoods. Opt Eng 40:971-983

Latrous S (1984) Pattern recognition and automatic zooplankton classification by image analysis: 1-117. Rennes-I University, Rennes

Löffler H (1963) Zur Ostrakoden- und Copepodenfauna Equadors. Arch Hydrobiol 59:196-234

Mielke W (2000) Two new species of Cletocamptus (Cope- 
poda: Harpacticoida) from Galápagos, closely related to the cosmopolitan C. deitersi. J Crustac Biol 20:273-284

Ortner P, Cummings SR, Aftring RP, Edgerton ME (1979) Silhouette photography of oceanic zooplankton. Nature 277:50-51

Pech-Pacheco JL, Alvarez-Borrego J, Orellana-Cepeda E, Cortez-Altamirano R (1999) Diffraction pattern applicability in the identification of Ceratium species. J Plankton Res 21:1455-1474

Pech-Pacheco JL, Alvarez-Borrego J, Cristóbal G, Keil M (2003) Automatic object identification irrespective to geometric changes. Opt Eng 42:551-559

Richard J (1897) Entomostracés de l'Amérique du Sud, recueillis par MM. U Deiters, H Von Ihering, GW Müller et CO Poppe. Mém Soc Zool Fr 10:263-301

Rocha-Olivares A, Fleeger JW, Foltz DW (2001) Decoupling of molecular and morphological evolution in deep lineages of a meiobenthic harpacticoid copepod. Mol Biol Evol 18: 1088-1102

Rolke M, Lenz J (1984) Size structure analysis of zooplankton samples by means of an automated image analyzing system. J Plankton Res 6:637-645

Editorial responsibility: Lisa Levin (Contributing Editor), La Jolla, California, USA
Suárez-Morales E, Reid JW, Iliffe TM, Fiers F (1996) Catálogo de los copépodos (Crustacea) continentales de la Península de Yucatán, México. Comisión Nacional para el Conocimiento y Uso de la Biodiversidad (CONABIO) and El Colegio de la Frontera Sur (ECO-SUR), Unidad Chetumal

Sun B, Fleeger JW (1994) Field experiments on the colonization of meiofauna into sediment depressions. Mar Ecol Prog Ser 110:167-175

Todaro MA, Fleeger JW, Hu YP, Hrincevich AW, Foltz DW (1996) Are meiofaunal species cosmopolitan? Morphological and molecular analysis of Xenotrichula intermedia (Gastrotricha: Chaetonotida). Mar Biol 125:735-742

Zacharias MA, Roff JC (2001) Explanations of patterns of intertidal diversity at regional scales. J Biogeogr 28: $471-483$

Zavala-Hamz VA, Alvarez-Borrego J (1997) Circular harmonic filters for the recognition of marine microorganisms. Appl Optics 36:484-489

Zavala-Hamz VA, Alvarez-Borrego J, Trujillo-Ortíz A (1996) Diffraction patterns as a tool to recognize copepods. J Plankton Res 18:1471-1484

Submitted: April 26, 2002; Accepted: September 12, 2002 Proofs received from author(s): February 18, 2003 